\title{
Conflict in commons: collective action and institutions
}

\section{Conflicto en comunes: acción colectiva e instituciones}

\author{
Sukumar Sarkar, Ph.D \\ Independent Researcher (Former UGC research fellow), Department of Economics, Calcutta \\ University56A, B.T. Road, Kolkata-700050 West Bengal, India Phone: 091-033-2557- \\ 5082/2528-4066 Fax: 091-033-2528-4066Email-ID: mrsukumarsarkar@gmail.com
}

Address for correspondence:

Sukumar Sarkar, Village: Chalkramroy, P.O. Gopalganj, Dist. Dakshin Dinajpur -733141, West Bengal, India, Telephone: (+91) 9432346649E-mail: mrsukumarsarkar@gmail.com

\begin{abstract}
Common pool resources (CPRs) are safe-guards and foundation for rural livelihood especially for the developing nations like India. Cooperation is needed to conserve CPRs due to its very features. Community institutions sometimes face conflicts to conserve commons cost-effectively. But, are conflicts always detrimental? Do they always hamper the local governance of commons? We have tried to view from close the activities of commons users and others and tried to understand the underlying symphony thereafter. In doing so, we have conducted a primary survey on 419 users of canal water, community forest and tank water in 11 CPRs dependent villages from West Bengal, India. We observed positive relations between conflict and collective action in conservation of commons. This finding seems to be conflicting with the notion that, conflict undermines collective action and therewith the potential for sustainability. We examined and found that successful informal communities are more conflictive and at the same time cooperative than formal one. We tried to see the working of different factors influencing collective action and conflicts. We also viewed the role of formal and informal institution in this orchestra of CPRs. The occurrences of supply, demand and policy side conflicts and conflict resolution methods are also not significantly different between formal and informal institutions. Therefore, conflict and informal institution have some positive impact for the successful conservation. We suggest that authorities have to study the nature and types of conflicts before implementing rules and institutional arrangements thereafter.
\end{abstract}

Keywords: commons, conflicts, collective action, institutions, conservation 


\section{INTRODUCTION}

Long before human civilization came into existence the earth was undergoing a continuous course of increasing its diverse environmental wealth which remained the foundation, the prime guiding force of human civilization. But, especially over the past few decades the marvel of blue planet is diminishing and we, her children observe with pain, the degradation every day. With this observation, we focus our attention on common pool resources (CPRs). The CPRs like biodiversity, biomass resources, canal irrigation, community fisheries, forest, land, livestock and tank water for irrigation have been degrading rapidly and causing the environmental crisis in general and agrarian crisis in particular in various developing countries. These are due to increase in unplanned industrialization and urbanization, population growth, demand supply disparity, climate and temperature change.

Commons are semi-public goods ${ }^{1}$ in nature and so potential beneficiaries cannot be excluded from using it. But, this leads to over-extraction and consequently to the tragedy of commons (Hardin 1968). According to Coase (1936), the solution to tragedy of commons is to hand over property right which internalizes the externality. But, this is not easy to impose due to high transaction cost, political inefficiency, asymmetric information and nonparticipation of local community etc. As a result, market approach and command and control based approach failed to manage commons. In some environments, higher social capital and collective action arrangements among commons' users can solve conflicts, free riding, non cooperation and divergence from a set of rules (Ostrom 1990; Pretty 2003). Pretty (2003) and other scholar have given much credence to the significance of social capital in commons. North (1990), Azuela (2006) and Nemarundwe (2003) claimed that institutional designs grant bargaining power of individuals or communities in commons conservation (Agrawal and Gibson 1999). A number of studies have attempted to address the mechanisms to manage commons sustainably ${ }^{2}$. The approach looked at prominent role of conflicts in canal water, fishery, forest, watershed and tank water irrigation management such as Kerr (2007), Bardhan and Dayton-Johnson (2002), Andersson et al. (2009),Janssen et al. (2011), Nygren (2000), Sarkar (2017a, 2017b), Sarkar and Ray (2019), Degen et al.(2000), Ostrom (1992),

\footnotetext{
${ }^{1}$ Due to features of CPR, exclusion of individual users is difficult to achieve and joint use involves subtractibility, i.e., the use of a resource by one person will subtract from another persons' enjoyment of the resource (Steins and Edwards 1998).

${ }^{2}$ Sustainable CPR conservation means that the demands of present generation cannot be the sole basis for deciding on appropriate solutions to CPRs use conflicts; needs of future generations and society in general needs to be considered as well (Muchena and van der Bliek 1997).
} 
Ostrom and Gardner (1993), Lubellet al. (2002), Sneddon (2002) and Suliman (1999). In CPRs literature Wade (1988), Ostrom (1990) and Vedeld (2000) found that misinterpretation of individual and consequent conflicts between individual members and sub-groups within a user's community are regularly reported. This may emerge counter-intuitive, because commons management requires cooperation, which can be argued to be seriously slowed down by disagreement and conflict (Olson 1965). In the literature, conflict can be defined as "any relationship between opposing forces whether marked by violence or not" (Desloges and Gauthier 1997). According to Ochieng Odhiambo (2000), "Each party wants to pursue its own interests to the full and in so doing ends up contradicting, compromising or even defeating the interest of the other." As noted by O'Leary and Bingham (2003) and Laerhoven and Andersson (2013), conflicts emerge from differences in values and worldviews, interests and uncertainty that surround various courses of action. We define conflict in commons conservation as - Power, Policy and Property (PPP) owners cleverly allocate more benefit and less cost in self-favour leaving the opposite for (their neighbor) Poor People (PP). Generally, the goal and objectives of rich (PPP) and the powerful may not be harmonious with the needs of the poor (PP) and the marginalized (Johnson et al. 2005; Baland and Platteau 1999). Literature reviews have shown that successful management of commons actually refers to community-based natural resource conflict management model (CBNRCMM). These studies view conflict deteriorate trust, which, in turn, drives cooperation negatively for higher transaction cost (Sarkar and Ray 2019). Thus, conflict can and must be settled at any cost. But, some practical verifications show the opposite.

Therefore, a couple of queries on commons conservation emerge. Is conflict always detrimental to collective action and conservation? If conflicts undermine trust, does formal institution resolve conflicts? How do institutions ${ }^{3}$, if at all, matter in moderating the detrimental impacts of conflicts? This research departs from this predictable analysis of conflict in commons. If conflict in commons undermines trust and cooperation, and if collective action in turn is necessary for the conservation of the commons, why we notice many evidences of conflicts where successful commons management goes together with reports of conflicts between its communities? Why conflictive informal institutions are also successful? Are the types of conflicts and mode of handling conflict different between formal and informal institutions?

In this study, it is argued that the articulation of disagreement and the consequent

\footnotetext{
${ }^{3}$ We use the words 'commons' interchangeably with common-pool resources. We focus here on smaller-scale natural resources, although commons exist at multiple scales and in all aspects of human society and 'institutions' and 'rules' interchangeably (North 1990).
} 
probability of conflict within commons user community are both inherent and necessary components of self-governance arrangements and a factor that complicates the organisation of the collective action and institutions (formal and informal) that are necessary to prevent tragedy of commons. Conflict may at the same time be indispensable and unwanted for sustainable management. We will also attempt to compare formal and informal institutions as we assume, both types, with their notable differences could have distinct influences on human behaviour towards sustainable management of commons.

We particularly explore the role of collective action (conflict) and institution. We examine the view that informal conflictive communities are also successful. On the basis of robust empirical instance we show that the more successful informal commons user communities also experience significantly more internal conflicts. In the following section, I discuss the study perspective along with the hypotheses. Finally, details of data collection and analysis, results, discussion and conclusion and recommendation and research gap will come up serially.

\section{STUDY PERSPECTIVE AND HYPOTHESES}

Evolution of Collective Action: 'Tragedy of the Commons' has been dominant in the discussion of sustainable management of commons (Baland and Plateau 1996). Hardin (1968) claimed that CPRs have been overexploited due to maximum use by individual. Privatisation or state regulation can play a major role to end their tragedy. Hardin used the term 'commons' to describe an open access grazing land situation (Steins and Edwards 1998). The methods were criticised for overlooking the actuality that many user communities have successfully managed commons by developing and maintaining self-governing ${ }^{4}$ institutions (Ostrom 1990). This criticisem has led to the development of common property theory, theory of collective action ${ }^{5}$, social capital theories ${ }^{6}$ and game theory about institutions from various disciplines. Today, there is no single extensively accepted or integrated theory on the applicable institutions for commons management (Agrawal 2001). In some circumstances, high and positive levels of social capital and collective action arrangements can mitigate commons management problems. Canal water, community forest and tank water are

\footnotetext{
${ }^{4}$ Governance includes the design institutions, setting of rules, the application of rules and the enforcement and adjudication of rules (Fenny 1988).

${ }^{5}$ Collective action emerges when the joint efforts of two or more individuals are needed to accomplish an common outcome (Sandler 1992).

${ }^{6}$ Social capital is the shared knowledge, understandings, norms, rules, connectedness and expectations about patterns of interactions that groups of individuals bring to a recurrent activity (Ostrom 1999).
} 
important commons that contribute to rural livelihoods. Collective action is necessary to sustain the resources and the resource-based earnings. Davies et al. (2004) distinguish two types of collective actions which are cooperation and coordination. Cooperation implies bottom-up, farmer-to-farmer collective action, while coordination means top-down as well as agency-led collective action.

Collective action is important in preservation of commons as it affect proper management and, hence, has a direct bearing on the regeneration of commons in terms of agricultural productivity and income. There are different indicators of collective action related to commons, community and institutional arrangement and nestedness (figure 1). These include: investment in terms of time, resources and financial base; open and equal participation in decision-making; attitude towards the member of these groups, equality in benefit allocation; economic and livelihood impacts and reduction in vulnerability; mutual trust, internal norms and role clarity within community and participation in conflict resolution; setting the level of penalty, sanction (social or monetary), providing reward; information sharing and sense of accountability; knowledge sharing, spreading awareness and external nested linkage; building safety measures to avoid accidents; conservation of assets and technological progress.

To draw the hypotheses and also to link collective action and institutions with conservation of commons and conflicts, we rely on Meizen-Dick et al. (2004) and Sarkar and Ray (2019). Figure 1 suggests that a common setup for collective action is described by the characteristics of commons, community and institutional arrangements and nestedness. These determine collective action and we assume that it, in turn, positively affect conservation of commons and conflicts.

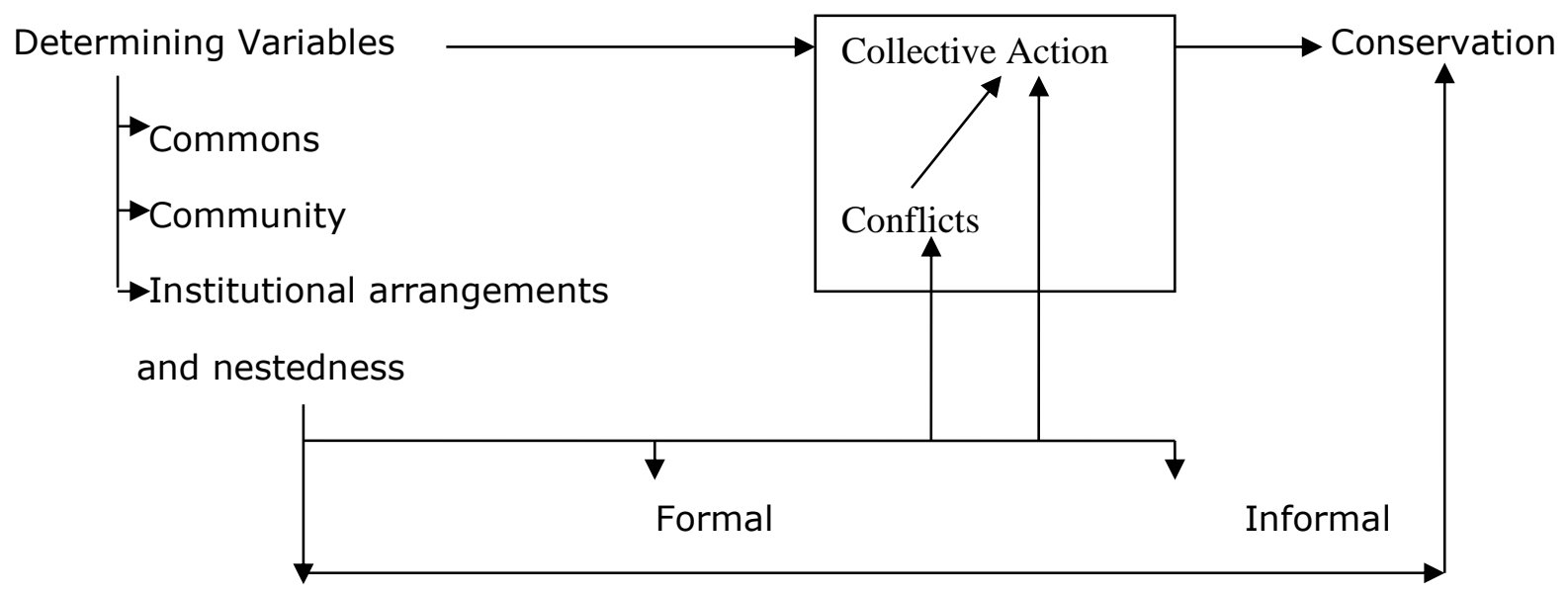


Figure 1: Development of collective action. Source: Sarkar and Ray (2019) with modification

A review engenders substantial optimism of decentralization policy to solve conflicts. But, non-cooperation needs to be addressed prior to cooperation about the institutional arrangements. There is a propensity to analyse 'conflict' and 'commons conservation' as separate and only successively related. Our implicit claim is that conflict is also consistent with sustainable commons governance. The conservation of commons may often require conflicts in order to change the existing governance and institutional arrangements for better. Successful community with high levels of collective action does not necessarily imply without conflicts.

Against this backdrop, we consider the following first hypothesis:

Hypothesis 1: conflict and collective action in commons are positively related.

Institutional Arrangement and Conflict Management: A number of study have investigated the different nature and types of institutions that persuade human behaviour and hence the sustainability of commons. Though, different points of views are instituted in prioritising the significance of formal and informal institutions, few scholars carry the design of North (1990) that both formal and informal institutions are important to attain sustainability. Informal institutions are often well-known as social norms. According to Posner (1997), social norms are specified force by four types of incentives for individuals to follow them. Firstly, some norms are self-enforcing because they are nuts and bolts to advantageous transactions. Secondly, they can be enforced by social disapproval, the effectiveness lies in its hidden danger of exclusion from ongoing advantageous transactions. Thirdly, compliance with norms might sometimes be due to emotional reasons. Finally, norms might be internalised and therefore obeyed to avoid feelings of guilt or shame. He recognised that in any given situation compliance is likely to be affected by a mix of these incentives. But, Ribot et al. (2008) claimed that the existence of democratic formal institutions is vital for conservation of commons. Others noted that the cooperation of stakeholders in the decisionmaking of sustainable commons conservation matters more than the type of institutional arrangement. Such institutions guarantee the rights of commons users and prevent external users from benefiting from the community's conservation activities (Pagdee et al. 2006). A system of authority within the community of commons users and external support in the enforcement of rules helps to stabilise institutions that conserve commons in a sustainable manner (Chakraborty 2001). 
Most authorities and agencies have underrated the capacity of local groups to participate effectively in commons management programmes (Esenjoraf 2004), some investigators noted that even those project which depend on community involvement have not been effective in targeting the poor (Mansuri and Rao 2004). The relationship of the community with the external authorities and the institutional designs which govern human behaviour towards sustainability is crucial (Agrawal and Gibson 1999). The term institution is conceptualized by different authors in different ways. The definition by North (1990) is used as the main point of reference, because it emphasises the differences between the formal and informal natures that institutions could have ${ }^{7}$ (table 1 ). Informal institutions are arrangements of rules and decision-making methods which have evolved from endogenous socio cultural backgrounds and give rise to social practices, assign roles to users and guide interactions among them (Appiah-Opoku and Mulamoottil 1997). Formal institutions refer to the rules that guide access, control and conservation of commons and which are backed up and enforced by the state (Leach et al. 1997).

The fundamental role played by institutions is being increasingly recognised in development studies (Ghate and Nagendra 2005). The discourse among scholars has emphasised on the success of different types of institutional designs. Studying institutions that govern CPRs conservation is crucial as CPRs are vital assets for the poor people (PP). Moreover, most of the biodiversity in developing nation (DN) reside in the commons, especially under systems of low intensity management (Lovett et al. 2006). Commons are means of livelihood for many rural people and rural poverty alleviation in DN requires its sustainable management. However, sufficient studies are not available on the effectiveness of institutions in sustainable management of CPRs. This literature review will therefore try to throw some light on the effectiveness of institutions in this field by comparing the effectiveness of formal and informal institutions there (table 1).

Table 1: Differences between informal and formal institutions

\begin{tabular}{ccc}
\hline Features & Informal & Formal \\
\hline Evolution & Endogenous & Exogenous \\
Nestedness & Low & High \\
External support & Low & High \\
Social embeddedness & High & Low \\
Enforcement and monitoring & Community & State \\
\hline
\end{tabular}

\footnotetext{
${ }^{7}$ There are various types of institutions such as formal and informal, indigenous and non-indigenous, local and external, traditional and non-traditional, endogenous and exogenous, and de facto and de jure referring to different aspects of institutions including enforcement characteristics, origins, presence of cultural element, and property rights. But, we have considered the terms formal and informal institutions whether backed by state law or not in the existing condition.
} 


\section{Source: Author's understanding}

If in an organization monitoring, appropriation, provision, conflict resolution and overall governance activities are structured in multiple layers of nested enterprises, it is more likely to succeed. In our context, cooperation among resource users, social norms, selfenforcement and monitoring by social disposal and compliance with norms are better in informal community. We see the types of institution, formal as well as informal of a resource user community in shaping the nature and extent of collective action (conflicts). The framework (figure 1) further suggests that collective actions emerge from the group size (community) and heterogeneities (Sarkar 2000a) and the associated conflicts relating to formal and informal institution of the group. The framework also suggests that outcome can be affected directly by the determining factors.

Therefore, we consider the following second hypothesis:

Hypothesis 2: successful informal communities are more conflictive and cooperative than formal community.

Conflict in Commons and Resolution: According to literature review, collective action (conflict) and conservation of commons are very closely related. Community faces various types of conflict (Appendix A) in canal irrigation, community forest and tank irrigation (Sarkar 2017a; Sarkar 2017b; Sarkar and Ray 2019; Sarkar 2020b). We categorize conflicts as supply side, demand side and policy side conflicts (table 2). Supply side conflicts connect to the maturity or optimal size of the resource units and the productive nature of the resource. It generally arises from deficient investments in the conservation and regeneration in protection and in depletion of commons. Demand side conflicts are linked to address allocating the resources in an efficient and equitable manner. The policy side or management and external user side conflicts ("Body" as used by local people instead of executive committee members in forest and water masters in the canal and tank irrigation) between communities, manager (policy maker) and external or outside users. Policy side conflicts are closely connected with the design of institution.

Table 2: The types of conflict in commons

\section{TYPES OF CPR CONFLICTS}

\begin{tabular}{ccc}
\hline & TYPES OF CPR CONFLICTS & \\
\hline Supply Side & Demand Side & Policy Side \\
Conservation conflicts & Extraction conflicts & External users \\
Protection conflicts & Interfering conflicts & Co-ordination failure \\
Depletion conflicts & Allocating conflicts & Governance conflict \\
\hline
\end{tabular}




\section{Souse: Author's understanding}

In our study sites the operational rules are both formal and informal. As in each setting the resource users themselves are the primary designers of the institutional arrangements, they are also the initial settlers of conflicts that come up. Even if the specific mechanism varies, people commonly rely on the following fundamental procedural modes to handle conflicts. Adjudication: dependence on judiciary where from final solution generates; Arbitration: a person or a group accepted by both conflicting side may offer some mutually agreeable solution; Avoidance: matters related to conflicts are generally mentioned within the periphery with no outside linkage; Coercion: imposing forcefully one's decision upon the others; Mediation: selecting a mutually a third personas mediator; Negotiation: while people from within the group exchanging views to solve a conflict may voluntarily end up with an agreeable way out (Castro and Nielson2003).

Thus, we consider the following third and final hypothesis:

Hypothesis 3: presences of supply, demand and policy side conflicts and conflict resolution methods are not significantly different between formal and informal institutions.

\section{METHODS AND MATERIALS}

Survey Site and Data Collection: Agriculture is the main activity of the villagers in our study sites. Poverty, illiteracy, unemployment and unequal earning opportunities have fostered social disparity as compared to their neighbours housed in better areas in or around the district head quarters with better communications, free or low cost educational and health care facilities. The villagers of Alipurduar site in particular and those in entire district in general are crippled with low earning opportunities and hence are almost solely dependent on forest. Agricultural activities are better in Bardhaman district. In fact, it is the best in the state of West Bengal. Here yield/acre, though low as compared with others state of India, tops West Bengal. The source of agricultural water is the community canal and tank water which irrigates 245.63 thousand hectares of agricultural land. On the other hand, engagement of people of the villages of the West Midnapure district in secondary sector like the industry based on NTFPs, cement, paper and food processing industry moderately high than the other two districts. The forest area of this district is spread over 171935 hectares of land. Midnapure canal is the most important source of irrigation water (267.92 thousand hectares). Besides the canal, the district is also rich in tank water. Therefore, people of Bardhaman and West Midnapure are forest and canal water dependent. A recurrent phenomenon that adversely 
affects the local economies of Alipurduar and West Midnapure is human-wildlife (elephant) conflict.

The disparity in topological condition, development opportunity, biodiversity, economic dependency, human-wildlife (elephant) conflicts and persistent institution-people conflicts characterizes the study sites.

To investigate the involvement of conflict and its influence on commons, we had selected randomly 419 households from eleven villages of the said districts of West Bengal, India $\left(21^{\circ} 20^{\prime}\right.$ to $27^{\circ} 32^{\prime} \mathrm{N}$ and $85^{\circ} 50^{\prime}$ to $89^{\circ} 52^{\prime} \mathrm{E}$ ). The data used in this study was collected from the primary survey which was carried out from September 2016 to July 2017 and December 2018 to July 2019 in several intervals. We have also collected some secondary data from District Statistical Handbooks, West Bengal, India (Census 2011) and from records of Divisional Forest and Sectional Irrigation Office. We have got more authentic information only from formal institution.

The questionnaires were pre-tested in the pilot survey. The households are mutually exclusive and less heterogeneous. Since the literacy level of the villagers is low the questionnaire was implemented on a face-to-face manner. We have also cross-checked the collected data with the local authority such as local self-government members, foresters, key informants like teachers of the local primary schools and the dwellers of neighboring villages. This two-step verification ensures the reliability of the collected data.

Measurement of Variables: We have taken three variables to assess their impact on commons conservation. They are as under:

Conflict: We measure conflict in terms of lack of cooperation (Sarkar 2017a). We have captured conflicts based on fifteen indicators from the last five seasons (Appendix A).

Collective action: We define collective action based on ten indicators following Sarkar and Ray (2019) and Sarkar (2020a). We have applied a five point Likert format (Likert 1932) with the response categories for each indicator ranging from very low (1) to very high (5) to assess collective action. Indicators are given the same weight for simplicity. We have calculated the mode value of each indicator in total scoring of the index which with the lowest score of 1 , leads to a total score of 10 and with the highest score of 5 , leads to a total score of 50.8

${ }^{8}$ Since the indicators are very much contextual, majority opinions are more important than the averages. Also, it is
important to note that since the study villages are located side by side, they are less heterogeneous as mentioned earlier. 
Institutional effectiveness: We have constructed a quantitative index based on qualitative and quantitative information to evaluate institutional effectiveness of the communities using 5 types of practice of the community and authority for conflict management (Sarkar 2017a). The information based on: (1) Alliance between community and authorities (Governmental Departmental Office) for conflict resolutions; (2) Success rate of the department for conflict resolutions (departmental hierarchy from base to the top); (3) Physical infrastructure (number of forest police or water master in the office against the sanctioned post) ${ }^{9}$; (4) Patrolling of the police (forest guard and water master). In this case the scoring rules are: every day is $10 ; 2-3$ times in a week is 5 and no patrolling or a single day per week is 0 and (5) Types of punishment and reward. A combination of monetary and non-monetary is 10 , either monetary or non-monetary is 5 and otherwise the score is 0 .

Statistical Analysis: We have used Spearman's rank correlation, Chi squared and paired t tests for the data analyses.

\section{RESULTS AND DISCUSSION}

Table 3:General information of the studied villages

\begin{tabular}{|c|c|c|c|c|c|c|c|}
\hline $\begin{array}{c}\text { Serial } \\
\text { no. }\end{array}$ & $\begin{array}{l}\text { Name of the } \\
\text { Villages }\end{array}$ & $\begin{array}{c}\text { Status } \\
\text { of } \\
\text { CPRs }\end{array}$ & $\begin{array}{l}\text { Village } \\
\text { Household }\end{array}$ & $\begin{array}{c}\text { Canal (C) } \\
\text { Irrigation } \\
(\mathrm{Ha})\end{array}$ & $\begin{array}{c}\text { Forest } \\
(\mathrm{F}) \operatorname{Areas}(\mathrm{Ha})\end{array}$ & $\begin{array}{c}\text { Tank }(\mathrm{T}) \\
\text { Irrigation } \\
(\mathrm{Ha})\end{array}$ & Status of institutions \\
\hline 1 & $\begin{array}{l}\text { Chhoto Chandabilla } \\
\text { (West Medinipur) }\end{array}$ & $\mathrm{F}+\mathrm{T}$ & 55 & & 77.29 & $(40.9) 1.5$ & Formal and Informal \\
\hline 2 & $\begin{array}{l}\text { Chowkir Boss } \\
\text { (Alipurduar) }\end{array}$ & $\mathrm{F}$ & 176 & & 509.00 & & Formal \\
\hline 3 & $\begin{array}{l}\text { Gadadhar FV } \\
\text { (Alipurduar) }\end{array}$ & $\mathrm{F}$ & 314 & & 1433.86 & & Formal \\
\hline 4 & $\begin{array}{c}\text { Gonna } \\
\text { (Bardhaman) }\end{array}$ & $\mathrm{C}+\mathrm{T}$ & 300 & $(301.6) 183.2$ & & (301.6)94.3 & Informal \\
\hline 5 & $\begin{array}{l}\text { Joyalbhanga (West } \\
\text { Medinipur) }\end{array}$ & C & 57 & $(45) 20$ & & & Informal \\
\hline 6 & $\begin{array}{l}\text { Lakshmiganj } \\
\text { (Bardhaman) }\end{array}$ & $\mathrm{C}+\mathrm{F}+\mathrm{T}$ & 177 & (192.2)123 & 176.31 & $(192.2) 17$ & Formal and Informal \\
\hline 7 & $\begin{array}{l}\text { Majhergram } \\
\text { (Bardhaman) }\end{array}$ & $\mathrm{C}+\mathrm{T}$ & 505 & $(285) 251.1$ & & $(285) 33.9$ & Informal \\
\hline 8 & $\begin{array}{l}\text { Pachami (West } \\
\text { Medinipur) }\end{array}$ & $\mathrm{F}+\mathrm{T}$ & 96 & & 40.00 & (73.8)10.8 & Formal and Informal \\
\hline 9 & $\begin{array}{l}\text { Salboni (West } \\
\text { Medinipur) }\end{array}$ & $\mathrm{C}+\mathrm{F}$ & 135 & (16)16 & 21.00 & & Formal and Informal \\
\hline 10 & $\begin{array}{l}\text { Shirsi (West } \\
\text { Medinipur) }\end{array}$ & $\mathrm{C}+\mathrm{T}$ & 122 & $(68.2) 47.1$ & & $(68.2) 21.1$ & Informal \\
\hline 11 & Suata (Bardhaman) & $\mathrm{C}+\mathrm{F}+\mathrm{T}$ & 326 & $(180.9) 166.7$ & 191.00 & $(180.9) 14.1$ & Formal and Informal \\
\hline
\end{tabular}

\footnotetext{
${ }^{9}$ The scoring rules are from 1 to 3 : more than 50 percent is 10 ; less than 50 percent is 5 and incase of absence the
} scoring value is 0 . 
Source: primary survey and blank cells imply that the particular CPR is not present in that village. In case of canal and tank irrigation figures in brackets indicate irrigated lands.

Table 3 shows significant correlation between canal command area and the total irrigated area $(p=0.00)$. The table also shows significant relationship between total irrigated land and tank irrigated land ( $p=0.052$ ). We observed livelihoods of the village people are highly dependent on the presence of commons in the villages. It also shows the nature of institutional arrangement across the study villages.

Table 4: The hierarchical departmental structure

\begin{tabular}{cccc}
\hline $\begin{array}{c}\text { Institutional } \\
\text { Structure }\end{array}$ & Canal Irrigation & Community Forest & Tank Irrigation \\
\hline State & $\begin{array}{c}\text { Irrigation and Waterways } \\
\text { Department (Jalasampad Bhavan) }\end{array}$ & $\begin{array}{c}\text { Government of West Bengal Directorate } \\
\text { of Forests (Aranya Bhavan) }\end{array}$ & Absent \\
District & Divisional Office & Divisional Forest Office & Absent \\
Sub-Divisional & Sub-Divisional Office/s & Range Office/s & Absent \\
Block & Sectional Office/s & Beat Office/s & $\begin{array}{c}\text { Local self- } \\
\text { government } \\
\text { (panchayet in India) } \\
\text { Absent }\end{array}$ \\
\end{tabular}

Source: Author's understanding

Table 4 shows the prevailing institutional arrangement present in the study site. It illustrate canal and tank irrigation is working without community level formal committees (water user association). Although, there are canal water departmental hierarchy and forest departmental hierarchy but no such departmental hierarchy is present in tank water. Local self-government is taking the responsibility for tank management.

Table 5: Collective action and level of conflicts across commons

\begin{tabular}{|c|c|c|c|c|c|c|c|}
\hline \multirow[b]{2}{*}{$\begin{array}{c}\text { Name of the } \\
\text { village }\end{array}$} & \multicolumn{2}{|c|}{ Canal Water } & \multicolumn{2}{|c|}{ Community Forest } & \multicolumn{2}{|c|}{ Tank Water } & \multirow[b]{2}{*}{$\begin{array}{l}\text { Institutional } \\
\text { effectiveness }\end{array}$} \\
\hline & 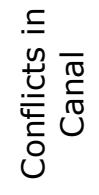 & 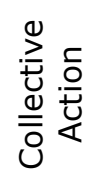 & 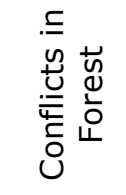 & 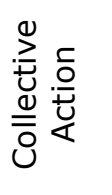 & 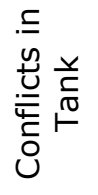 & 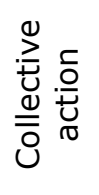 & \\
\hline $\begin{array}{c}\text { Chhoto } \\
\text { Chandabilla }\end{array}$ & & & 38 & 17 & 6 & 13 & 10 \\
\hline Choukir Boss & & & 15 & 42 & & & 50 \\
\hline Gadadhar & & & 54 & 38 & & & 50 \\
\hline Gonna & 33 & 34 & & & 17 & 34 & 50 \\
\hline Joyalbhanga & 4 & 18 & & & & & 10 \\
\hline Lakshmiganj & 24 & 26 & 19 & 32 & 13 & 21 & 50 \\
\hline
\end{tabular}


Sustainability, Agri, Food and Environmental Research, (ISSN: 0719-3726), 9(2), 2021: 185-204 http://dx.doi.org/10.7770/safer-VONO-art2352

\begin{tabular}{cccccccc}
\hline Majhergram & 37 & 33 & & & 26 & 31 & 50 \\
Pachami & & & 35 & 24 & 4 & 19 & 20 \\
Salbani & 8 & 19 & 31 & 27 & & & 30 \\
Shirsi & 11 & 21 & & & 2 & 14 & 10 \\
Suata & 39 & 31 & 27 & 29 & 19 & 26 & 50 \\
\hline
\end{tabular}

Source: primary survey and no of conflicts are in the last five seasons.

Table 5 illustrates conflicts in tanks which indicate the occurrence of conflicts in tank resource and use of tank water as irrigation with village level cooperation. We found direct relation between conflicts and collective action $(p=0.013)$. This is rather surprising and supported by the finding of Laerhoven and Andersson (2013). We find not significant but negative relation between conflicts and collective action ( $p=0.640)$ in forest. In canal irrigation, collective action and level of conflicts positively correlated $(p=0.000)$. Table shows conflicts are high in those villages which are also highly motivated to share water. Gibson et al. (2000) shown that conflicting resource user groups do not essentially fail to conserve their commons successfully over an extended period of time. A few possible explanations with reference to our study may be due to: the absence of water user associations (WUA) in canal and tank villages which are successfully operative with informal institutions only; moderate nestedness and resource units are mobile and are subject to seasonal exhaustion.

We have seen the usefulness of institutions when they go hand in hand with their informal parallels. In the table 5 it appears that formal institutions like joint forest management committees (JFMCs) in community forest are normal trouble shooters and bring settles a good number of conflicts subsequently. On the other hand, having only informal institutions in canal and tank water irrigation (with high collective action) conflicts are high.

Table 3 and 5 illustrate the strength and weakness of the institutional arrangement across study villages. In most of the cases formal and combination of formal and informal institutions are simultaneously effective to resolve conflicts. On the other hand, informal institutions are more conflictive and cooperative to resolve conflicts. There are the results of social connectedness, mutual trust and respect among the villagers. But, informal institutions are not institutionally effective mostly. This result is also supported by Ostrom's (2004) findings.

Table 6:Types of conflicts across the commons

\begin{tabular}{lccccc}
\hline Types of conflicts & Canal & Forestry & Tank & Formal & Informal \\
\hline Supply Side(56) & 8 & 37 & 11 & 37 & 19 \\
Demand Side(253) & 96 & 103 & 54 & 103 & 150 \\
Policy Side(153) & 52 & 79 & 22 & 79 & 74 \\
\hline
\end{tabular}

Source: Primary survey. 
The types of conflicts of common-pool resources in supply side, demand side and policy side are illustrated in table 6 . They are not significantly different between formal and informal $(p=0.430)$. This observation neither supports Posner (1973) nor against Ribot et al. (2008). But, the incidence of conflicts among canal irrigation, forest commons and tank irrigation ( $p$ $=0.001$ ) are significantly different. These may be due to split of resource units stock and mobile units. It reveals that frequencies of conflicts have a close link with the institutional arrangement.

Table 7: Conflict resolutions across the commons and institutions

\begin{tabular}{cccccc}
\hline Mode to handle conflict & Canal & Forest & Tank & Formal & Informal \\
\hline Adjustment & 2 & 18 & 0 & 18 & 2 \\
Arbitration & 27 & 60 & 11 & 60 & 38 \\
Avoidance & 23 & 37 & 14 & 37 & 37 \\
Coercion & 26 & 36 & 27 & 36 & 53 \\
Mediation & 31 & 44 & 14 & 44 & 45 \\
Negotiation & 47 & 24 & 21 & 24 & 68 \\
\hline
\end{tabular}

Source: primary survey.

Table7 shows the method of conflict resolutions is different across the commons and institutions. It shows a significant difference between tank and forest resources $(p=0.005)$. Modes of handling conflicts are not significantly different between forest and canal ( $p=$ 0.122 ). Although, both tank and canal resources are used for irrigation purpose, the methods of conflict management are significantly different $(p=0.065)$. Again, table shows no significant difference to conflict resolution methods between formal and informal institutions $(p=0.360)$. Therefore, the effectiveness of formal and informal institutions is same (North 1990).

As conclusion and policy implication, while identifying the ups and downs in CPRs overall development, we have come through some findings which, if used properly, may throw some hopeful rays on the lives of the resources and its users simultaneously. Ups like high collective action, timely and amicable settlement of conflicts and proper use of institutions in managing commons and, Downs, just the other ways round. These three variables in our research are crucial to maintain and/or improve the smile of CPRs sustainable.

The conventional study observed high collective action (conflicts) implies low conflict (collective action) among resource users. This study shows collective action and conflicts go hand in hand especially with canal and tank water irrigation. Successful informal communities are more conflictive and cooperative to conserve commons. Different types of conflicts and resolution methods between the formal and informal community also not significantly 
different. Therefore, some changes may generate from conflicts that promote cooperation and conservation of commons. We suggest that at least a mild degree of conflict is necessary for effective and appropriate institutional arrangements. Conflicts are high in communities where an underlying tendency for united action already exists. Government authorities have multiple roles to play in the governance of CPRs. Resource users are often found incapable in addressing troublesome problems alone. Authorities, in consultation with user representative may be in a better position to handle crucial situation and implement some appropriate agreements to solve different issues.

Conflicts, generally defined as lack of cooperation among members, are subject to some limitations. This is because the definition varies in different socio-economic scenario. Significant gap left for future studies: identification of resource specific and area specific negative and positive conflicts and their settlement thereafter for the sustainable management of common pool resources.

Conflicts are good if they do good and mature to cooperation...a life donor to life itself...a search that goes on and on.

\section{ACKNOWLEDGMENTS}

The data used in this article are from a survey designed with the help of the local selfgovernment (present and ex-panchayet pradhan) and a number of Government officials, staff of canal and forest department, ICDS staff and primary school teachers employed there. Author thanks them along with the 419 villagers for their participation and cooperation in this study. I convey my heartiest thanks to the Editor of the journal and referees for their valuable and constructive comments which have given me some food for thought. The usual disclaimer applies.

\section{RERERENCES}

Agrawal, A. 2001. Common property institutions and sustainable governance of resources. World Development, 29(10): 1649-1672.

Agrawal, A. and C. Gibson. 1999. Enchantment and disenchantment: The role of community in natural resource conservation. World Development, 27(4): 629-649. 
Andersson, K., Gordillo, G. and Van Laerhoven, F. 2009. Local Governments and Rural Development: Comparing Lessons from Brazil. Chile, Mexico, and Peru. University of Arizona Press, Tucson.

Appiah-Opoku, S. and G. Mulamoottil. 1997. Indigenous institutions and environmental assessment: The case of Ghana. Environmental Management, 21(2): 159-171.

Azuela, A. 2006. Illegal logging and local democracy: Between communitarianism and legal fetishism. Ambient Soc, 9(1).

Baland, J. M. and Platteau, J. P. 1996. Halting degradation of natural resources: Is there a role for rural communities. Oxford: FAO and Clarendon Press.

Baland, J. M. and Platteau, J. P. 1999. The Ambiguous Impact of Inequality on Local Resource Management. World Development, 27(5): 773-788.

Bardhan, P.K. and Dayton-Johnson, J. 2002. Unequal irrigators: Heterogeneity and commons management in large-scale multivariate research. In: National Research Council. The drama of the commons. National Acadamy Press, Washington.

Castro, A.P. and Nielsen, E. 2003. Indigenous people and co-management: implications for conflict management. Environmental Science and policy, 4 (2001): 229-239.

Census, 2011. District Statistical Hand Book, Ministry of Home Affairs, Government of India: (http://www.censusindia.gov.in/2011census/dchb/DCHB.html).

Chakraborty, R. 2001. Stability and outcomes of common property institutions in forestry: Evidence from the Terai region of Nepal. Ecological Economics, 36(2): 341-353.

Coase, R. 1960. The Problem of Social Cost. Journal of Law and Economics, 3: 1-44.

Davies, B., Black stock, K., Brown, K., and Shannon, P. 2004. Challenges in creating local agri-environmental cooperation action amongst farmers and other stakeholders, The Macaulay Institute, Aberdeen.

Degen, P., Van Acker, F., Van Zalinge, N., Thuok, N. and Vuthy, L. 2000. Taken for granted. Conflicts over Cambodia's freshwater fish resources. IASCP Conference 2000, Bloomington.

Desloges, C. and Gauthier, M. 1997. Community Forestry and Forest Resource Conflicts: An Overview. Paper prepared for the XI World Forestry Congress, Antalya, FAO Forestry Department, Turkey.

Esenjoraf, A. 2004. A community-based conservation programme for the management and conservation of land resources in Lesotho. Ph.D. dissertation, Department of Sociology of the Faculty of Humanities, University of the Free State Bloemfontein, Republic of South Africa. 
Feeny, D. 1988. The demand for and supply of institutional arrangements. In Rethinking institutional analysis and development (eds. Ostrom, V., D. Feeny and H. Picht). San Francisco: ICS Press.

Ghate, R. and H. Nagendra. 2005. Role of monitoring in institutional performance: Forest management in Maharashtra, India. Conservation and Society, 3(2): 509-532.

Gibson, C., Mckean, M. and Ostrom, E. 2000. (eds.)People and forests. Communities, institutions, and governance. MIT Press, Cambridge, MA.

Hardin, G. 1968. Tragedy of Commons. Science, 162: 1243-1248.

Janssen, M.A., Anderies, J.M. and Cardenas, J.C. 2011. Head-enders as stationary bandits in asymmetric commons: Comparing irrigation experiments in the laboratory and the field. Ecological Economics,70(9): 1590-1598.

Johnson, C., Deshingkar, P. and Start, D. 2005.Grounding the state: Devolution and development in India's Panchayats. The Journal of Development Studies,41(6): 937970.

Kerr, J. 2007. Watershed Management: Lessons from Common Property Theory. International Journal of the Commons, 1(1): 89-109.

Leach, M., R. Mearns and I. Scoones. 1997. Environmental entitlements: A framework for understanding the institutional dynamics of environmental change. IDS Discussion Article 359, Sussex.

Likert, R. 1932. A technique for the measurement of attitudes. Archive in Psychology, 22: 155.

Lovett, C., H. Quinn, G. Ockwell and R. Gregorowski. 2006. Two cultures and tragedy of the commons. African Journal of Ecology, 44: 1-5.

Lubell, M., Schneider, M., Scholtz, J.T. and Mete, M. 2002. Watershed partnerships and the emergence of collective action institutions. American Journal of Political Science,46(1): 148-163.

Mansuri, G. and V. Rao. 2004. Community-based and -driven development: A critical review. The World Bank Research Observer, 19(1): 1-39.

Meinzen-Dick, R., Di Gregorio, M. and McCarthy, N. 2004. Methods for studying collective action in rural development. Agricultural System, 82(3): 197-214.

Nemarundwe, N. 2003. Negotiating resource access: Institutional arrangements for woodlands and water use in southern Zimbabwe. Ph.D. dissertation, Swedish University of Agricultural Sciences, Uppsala.

North, D. 1990. Institutions, institutional change and economic performance. Cambridge: Cambridge University Press. 
Nygren, A. 2000. Environmental narratives on protection and production: Nature-based conflicts in Río San Juan, Nicaragua. Development and Change,31(4): 807-830.

Odhiambo, O. 2000. Addressing natural resources conflict throughout community foresty: The case of Eastern Africa. Paper Prepared for: E-Mail Conference 'Addressing Natural Resource Conflicts Through Community Forestry' January - March, 1996.

O'Leary, R. and Bingham, L. 2003. (eds). The promise and performance of environmental conflict resolution.RFF Press, Washington.

Olson, M. 1965. The Logic of Collective Action: Public Goods and the Theory of Groups. Cambridge: Harvard University Press.

Ostrom, E. 1990. Governing the commons: the evolution of institutions for collective action. Cambridge: Cambridge University Press.

Ostrom, E. 1992. Crafting institutions for self-governing irrigation systems. ICS Press, San Francisco.

Ostrom, E. 1999. Social capital: A fad or a fundamental concept. In: Social capital: A multifaceted perspective (eds. Dasgupta, P. and I. Serageldin). Washington DC: World Bank.

Ostrom, E. 2004. Understanding collective action. In: Meinzen-Dick R, Gregorio M Di (eds) Collective action and property rights for sustainable development, 2020 vision for food, agriculture and the environment. Focus 11, IFPRI International Food Policy Research Institute, Washington.

Ostrom, E. and Gardner, R. 1993. Coping with Asymmetries in the Commons: Self-Governing Irrigation Systems Can Work. Journal of Economic Perspectives,7(4): 93-112.

Pagdee, A., Y. Kim and P. Daugherty. 2006. What makes community forest management successful: A meta-study from community forests throughout the world. Society and Natural Resources, 19: 33-52.

Posner, R. A. 1997. Social norms and the law: An economic approach, American Economic Review, 87(2): 365-369.

Pretty, J. 2003. Social capital and the collective management of resources. Science, 302: 1912-1915.

Ribot, J., A. Chhatre and T. Lankina. 2008. Institutional choice and recognition in the formation and consolidation of local democracy representation, Equity and Environment. Working Article No. 35. World Resources Institute.

Sarkar, S. 2017a. Incentives and Community Forest. Journal of Human Ecology, 60(2,3): 96105. 
Sarkar, S. 2017b. Efficient Solution in Common Canal Irrigation. Agricultural Situation in India. Directorate of Economics and Statistics, Ministry of Agriculture and Farmers Welfare, 74(9): 23-31. (https://eands.dacnet.nic.in/PDF/December2017.pdf)

Sarkar, S. and Ray, B. 2019. Collective action and Tragedy of tank water. Arthaniti: Journal of Economic Theory and Practice,19(2):224-249.

Sarkar, S. 2020a. Social capital: The role of group size and heterogeneity. International Journal of Multidisciplinary, 5(8): 22-32.

Sarkar, S. 2000b. Cooperation and development outcome in micro watershed. Journal of Academic Research in Economics, 12(3): 552-571. (http://www.jaresh.com/downloads/nov_2020/sarkar.pdf).

Sandler, T. 1992. Collective action: Theory and applications. Michigan: University of Michigan Press.

Sneddon, C. 2002. Water conflicts and river basins: The contradictions of co-management and scale in Northeast Thailand. Society and Natural Resources,15(8): 725-741.

Stern, P., T. Dietz, N. Dolsak, E. Ostrom and S. Stonich. 2002. Knowledge and questions after 15 years of research. In: The drama of the commons (eds. National Resource Council). Pp. 445-489. Washington, DC: National Academy Press.

Steins, N. and V. Edwards. 1999. Platforms for collective action in multiple-use common-pool resources. Agriculture and Human Values, 16: 241-255.

Suliman, M. 1999. Managing the forest resources battlefield: Appreciating actor's roles and realities. In Food and Agriculture Organisation (FAO) Pluralism and sustainable forestry and rural development. Food and Agriculture Organisation (FAO), Rome.

Van Laerhoven, F. and Andersson, K.P. 2013. The Virtue of Conflict: An Institutional Approach to the Study of Conflict in Community Forest Governance. International Forestry Review, 15(1): 122-135.

Vedeld, T. 2000. Village politics: heterogeneity, leadership and collective action. Journal of Development Studies, 36(5):105-134.

Wade, R. 1988. Village republics. Economic conditions for collective action in South India. Cambridge University Press, Cambridge.

Received: 24th October 2020; Accepted: 24 ${ }^{\text {th }}$ December 2020;

First distribution: 07th January 2021. 
Appendix A. Conflict in the commons

\begin{tabular}{|c|c|c|}
\hline Canal water & Community forest & Tank water \\
\hline Head-tail problem & Absence of negotiators & $\begin{array}{l}\text { Free riding (water } \\
\text { rate) }\end{array}$ \\
\hline $\begin{array}{l}\text { Low quality of drainage- } \\
\text { Drains are lower than the } \\
\text { land }\end{array}$ & Illicit cutting of trees & $\begin{array}{l}\text { Drainage, dam, } \\
\text { spout problem }\end{array}$ \\
\hline $\begin{array}{l}\text { Outlet problem not properly } \\
\text { functioning }\end{array}$ & Grazing in forest and rangeland & $\begin{array}{l}\text { Appropriation of } \\
\text { resources }\end{array}$ \\
\hline $\begin{array}{l}\text { Clearing or, maintenance } \\
\text { problem (Villagers or by the } \\
\text { MGNREGS) }\end{array}$ & $\begin{array}{l}\text { Conflict between villagers and other } \\
\text { external user group }\end{array}$ & $\begin{array}{l}\text { Caste, class and } \\
\text { gender }\end{array}$ \\
\hline $\begin{array}{l}\text { Guard (PWD duty) not } \\
\text { monitoring effectively }\end{array}$ & Conflict at the policy level & $\begin{array}{l}\text { Monitoring, } \\
\text { reconstruction etc. }\end{array}$ \\
\hline $\begin{array}{l}\text { Illegal harvesting, } \\
\text { converting the channel } \\
\text { networks }\end{array}$ & Conflict between villagers and FD & With the authority \\
\hline $\begin{array}{l}\text { Land size, allocation } \\
\text { problem between the large } \\
\text { and small land holders. }\end{array}$ & $\begin{array}{l}\text { Conflicts related to forest boundary- } \\
\text { where does the CPR begin and } \\
\text { where does it stop? }\end{array}$ & $\begin{array}{l}\text { Willingness to } \\
\text { participate in } \\
\text { maintenance of } \\
\text { resources }\end{array}$ \\
\hline $\begin{array}{l}\text { Fishing to diverting the } \\
\text { water flow }\end{array}$ & $\begin{array}{l}\text { Conflicts duo to unequal access of } \\
\text { the benefits }\end{array}$ & $\begin{array}{l}\text { Illegal water } \\
\text { harvesting }\end{array}$ \\
\hline $\begin{array}{l}\text { Insufficient water, flood } \\
\text { problem }\end{array}$ & Conflicts for appropriation rules & $\begin{array}{l}\text { Operator } \\
\text { (technician) }\end{array}$ \\
\hline $\begin{array}{l}\text { Time of water supply and } \\
\text { collecting }\end{array}$ & $\begin{array}{l}\text { Conflicts due to the authority or } \\
\text { leadership }\end{array}$ & $\begin{array}{l}\text { Illiteracy of } \\
\text { households }\end{array}$ \\
\hline $\begin{array}{l}\text { Allocation wit in same land } \\
\text { holding. }\end{array}$ & $\begin{array}{l}\text { Conflicts over unequal contributions } \\
\text { to manage the forest }\end{array}$ & $\begin{array}{l}\text { Tank condition } \\
\text { (working conditions) }\end{array}$ \\
\hline $\begin{array}{l}\text { Power status-caste and } \\
\text { class }\end{array}$ & Governance such as forest guard & $\begin{array}{l}\text { Tank bed (channel } \\
\text { networks) }\end{array}$ \\
\hline $\begin{array}{l}\text { Deficiency of the gate } \\
\text { system or the chain system }\end{array}$ & Clearing (Planting) & $\begin{array}{l}\text { Distance from the } \\
\text { sources }\end{array}$ \\
\hline $\begin{array}{l}\text { Quota, not equal distribution } \\
\text { by the canal department }\end{array}$ & Hazardous activities & $\begin{array}{l}\text { Availability of water } \\
\text { and the level of } \\
\text { water }\end{array}$ \\
\hline $\begin{array}{l}\text { Water not reachable to } \\
\text { every plots }\end{array}$ & $\begin{array}{l}\text { Basic Infrastructure. (Spade, Hoe, } \\
\text { Grubber, Fencing) }\end{array}$ & $\begin{array}{l}\text { Fishery and } \\
\text { domestic activities }\end{array}$ \\
\hline
\end{tabular}

